Article

\title{
Levels of stress and coping strategies in family caregivers who treat schizophrenic patients with risk of violent behavior
}

\author{
Miftahul Janah, ${ }^{1}$ Giur Hargiana ${ }^{2}$ \\ ${ }^{1}$ Faculty of Nursing, Universitas Indonesia, Depok, West Java; ${ }^{2}$ Department of Mental Health Nursing, Faculty \\ of Nursing, Universitas Indonesia, Depok, West Java, Indonesia
}

\begin{abstract}
Background: Violent behavior is one of the most common symptoms of people who have schizophrenia. Caring for family members who have schizophrenia can be a stressor for other family members. The stressors can be stressful for the caregiver. Family caregivers require coping strategies to overcome the stressors. This study aims to determine the relationship between stress levels and coping strategies of family caregivers who treat schizophrenic patients with a risk of violent behavior.

Design and Methods: The research design engaged crosssectional with the purposive sampling technique by involving 87 caregiver families who who treat schizophrenic patients. The data was collected by using the Perceived Stress Scale (PSS) and Ways of Coping (WOC) questionnaires. This study was analyzed by employing the Chi-Square test to determine the relationship between stress levels and coping strategies in the caregiver family.

Results: This study shows that stress levels are not significantly associated with coping strategies in family caregivers.

Conclusion: Good supports from health and social service professionals are required to help family caregivers cope with their stressors well.
\end{abstract}

\section{Introduction}

Schizophrenia is a chronic mental disorder that usually occurs at a young age and can affect brain functions, such as disrupting patterns of thought, perception, movement, and behavior. ${ }^{1}$ It is estimated that more than 21 million people worldwide are affected by schizophrenia. ${ }^{2}$ The data indicates that the number of schizophrenic sufferers had increased from 5.3 per mile to 7 per mile from 2013 to $2018 .^{3}$ The main problem that often occurs in schizophrenia patients is violent behavior ${ }^{4}$. The incidence of quarreling behavior in schizophrenics is $47 \% .{ }^{1}$ Nolan et al. documented the interviews and found that 11 out of 55 attacks in schizophrenic inpatients were directly associated with positive psychotic symptoms. ${ }^{5}$ This condition must be treated immediately because violent behavior can harm patients, other people, and the environment. ${ }^{4}$

Caring for family members with mental disorders can be a stressor for other families. The stressor results in stress and a burden on the family. A study at Dr. H. Soewondo Kendal Regional Public Hospital in Indonesia shows diverse levels of stress in families whose family members suffer from mental disorders; 52 people $(66.7 \%)$ experienced moderate stress, 18 people $(23.1 \%)$ experienced severe stress, and 8 people $(10.3 \%)$ experienced mild stress. ${ }^{6}$ When caring for family members with mental disorders, families need coping strategies to deal with the stress they face. Meanwhile, another study shows diverse coping strategies used by families in caring for patients with severe mental disorders; 20 people (47\%) utilized emotion-focused coping, 13 people (30\%) utilized problem-focused coping, and 10 people $(23 \%)$ used problem-focused coping and emotion-focused coping simultaneously. ${ }^{7}$ The family's stress experience and ineffective coping strategies can have an impact on mental disorder patients because they need their family's participation. Based on the phenomena described previously, the researchers are interested in investigating the level of stress experienced by families whose family members are at risk of violent behavior and the coping strategies used by the family caregivers.

\section{Design and Method}

This research is a cross-sectional research study. The research design engaged cross-sectional with the purposive sampling technique. Therefore, the sample size of this research was 87 family caregivers. The sample of this study was family caregivers who treated schizophrenic patients with a risk of violent behavior in Komunitas Peduli Skizofrenia Indonesia (KPSI). The criteria for the patient to be taken are schizophrenic patients who have experienced violent behavior. Data collection was carried out online starting from May $18^{\text {th }}$ to July $12^{\text {th }}, 2020$.

The data were collected using online questionnaire by considering research ethics, such as respect for human dignity, beneficence, non-maleficence, and justice. This research was

Significance for public health

This study has important public health benefit because this study indicates that the stress level that occurs in the family caregivers is categorized as a moderate level. Even though the family caregivers' stress level is at an intermediate level, this situation still requires attention, prevention, management, and treatment appropriately and effectively. Thus, it does not continue to a more severe level. 
approved by the Ethics Committee of the Faculty of Nursing, Universitas Indonesia, with decision number S741/UN2.F12.D1/PDP.O4.01/2020. The instrument employed in this study was the Perceived Stress Scale (PSS) and Ways of Coping (WOC) questionnaire. The stages of data processing were editing, coding, processing, and cleaning. The coded data were then analyzed by employing SPSS 23.0. The questionnaire in this study had previously been tested for its validity and reliability. The Ways of Coping (WOC) questionnaire has been tested for its validity and reliability. This questionnaire has a reliability level from 0.71 to 0.94 .

\section{Results}

This research reveals that the respondents are adults, females, housewives, diploma graduates, siblings of the schizophrenic patients, employees with lower monthly income than the regional minimum wage in Indonesia, and 7 work hours (median) to treat schizophrenic patients. Besides, the duration of schizophrenic patients suffering from their illness is about 1 to 10 years (Table 1).

The description of the respondents' stress was measured using PSS and the coping measured by WOC, the categorical results were analysed using frequency distribution values. Stress level and coping strategies discovered by looking at the total number and percentage of each category. Table 2 shows that the stress level of family caregivers is mostly in the medium category. However, there are still some family caregivers who experience severe stress levels. On the other hand, the lowest percentage shows that family caregivers experience a mild stress level.

Table 3 shows that family caregivers use one of the two coping strategies to care for schizophrenic patients with a risk of violent behavior. They are problem-focused coping (PFC) and emotionfocused coping (EFC). The use of the two coping strategies tends to be balanced. On the other hand, only a few family caregivers use a combination of the two types of coping strategies.

Table 4 shows that stress levels have no significant relationship to coping strategies in family caregivers whose patients are at risk of violent behavior.

\section{Discussion}

Stress is a physical and psychological response to the body when facing danger or threat. ${ }^{8}$ Medium stress level is the level of stress in situations, such as excessive workloads and uncompleted or incomplete tasks that every individual frequently feel and face. Thus, it can affect one's health condition that lasts longer than mild stress levels. ${ }^{9}$ When providing care to schizophrenic patients, family caregiver experience stress.

One of the roles and functions of the family is to provide affection for other family members in meeting their psychosocial needs. ${ }^{10}$ A study concludes that caregivers' caring for schizophrenic patients have a higher burden than caregivers caring for bipolar disorder patients, especially in terms of external supports, routine cares, and relationships with family members and other friends. ${ }^{11}$ Most of the studies investigating caregivers' burden of schizophrenic patients report that more than $90 \%$ of caregivers experience moderate to severe burden. ${ }^{12}$ Furthermore, the management of unpredictable psychiatric symptoms (such as violent behavior) of schizophrenic patients, especially patients who have a history of violent behavior, can cause stress and
Table 1. Description of the distribution of respondents' characteristics in Komunitas Peduli Skizofrenia Indonesia (KPSI).

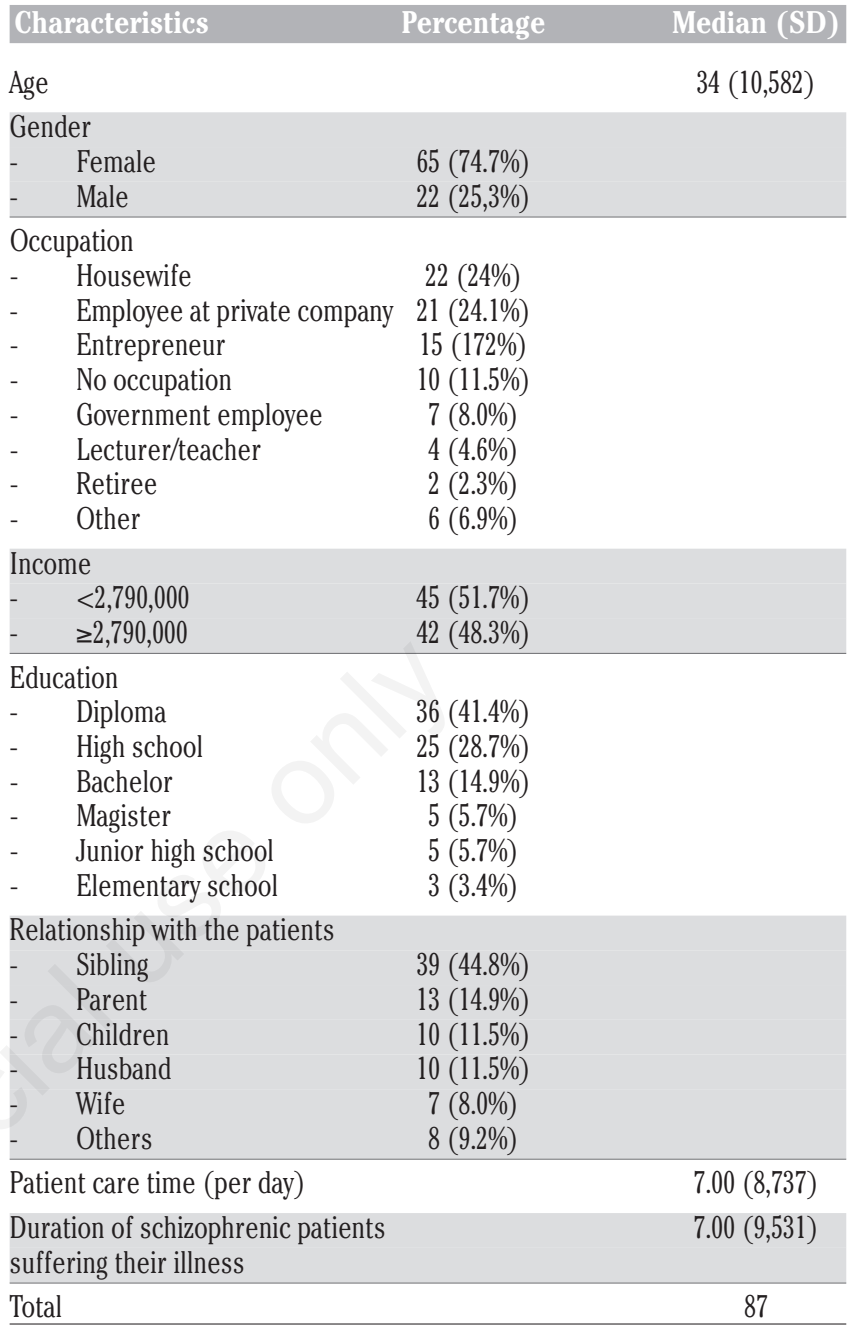

Table 2. Description of stress levels in Komunitas Peduli Skizofrenia Indonesia (KPSI).

\begin{tabular}{llcc} 
Variable & Category & Total (n) & Percentage (\%) \\
Stress levels & Mild & 7 & 8.0 \\
& Medium & 65 & 74.7 \\
& Severe & 15 & 17.2 \\
Total & & 87 & 100.0 \\
\hline
\end{tabular}

Table 3. Description of coping strategies in Komunitas Peduli Skizofrenia Indonesia (KPSI).

\begin{tabular}{llcc} 
Variable & Category & Total (n) & Percentage (\%) \\
\multirow{2}{*}{ Coping strategy } & Problem-focused coping & 41 & 47.1 \\
& Emotion-focused coping & 41 & 47.1 \\
& Problem-focused coping & 5 & 5.7 \\
Total & and emotion-focused coping & & \\
\hline
\end{tabular}

Table 4. Description of stress levels and coping strategies in Komunitas Peduli Skizofrenia Indonesia (KPSI).

\begin{tabular}{lcc} 
Variable & \multicolumn{2}{c}{ Coping strategies } \\
& N & p \\
Stress level & 87 & 0.807 \\
\hline
\end{tabular}


pressures on the caregivers. ${ }^{13}$ A study shows that $87.7 \%$ of caregivers experiencing psychological violence, and $75.8 \%$ of them experience physical violence by schizophrenic patients in Japan. ${ }^{14}$ Besides endangering themselves, other impacts that possibly arise from the violent behavior of schizophrenic patients are social ostracism from their friends and the possibility of a loss of jobs. ${ }^{4}$ Therefore, family caregivers who provide care to schizophrenic patients will be more at risk of experiencing stress. ${ }^{15}$

Coping strategies are defined as individual responses when they experience stress or when levels of stress exposure increase. Coping strategies can be classified into Problem-Focused Coping (PFC) and Emotion-Focused Coping (EFC). Family caregivers who tend to use PFC will deal with the problems or burdens they face by looking for alternatives to solve them. PFC consists of planful problem solving, confrontative coping, and seeking social supports. Another study shows that the most frequently used coping strategy by family caregivers is seeking social support, while the least used coping strategy is confrontation. ${ }^{16}$ Family caregivers tend to seek social supports and planful problem solving to reduce their burden because sharing the difficulties faced with others can relieve the perceived pressures. ${ }^{17}$ Another advantage that the family caregivers possibly obtain when using these coping strategies is getting additional information to solve it.

Emotional-Focused Coping (EFC) is a coping commonly used mainly to treat health problems because a threat to one's health is an event that is compulsorily tolerated but cannot necessarily be followed up. Therefore, caregivers use a coping that focuses on emotions to face the fact that one of their family members has a mental illness. ${ }^{18}$ This study reveals that several types of EmotionFocused Coping (EFC) performed by caregivers have different percentages: distancing $(65.06 \%)$, accepting responsibility $(65 \%)$, escape/avoidance $(58.97 \%)$, self-control $(53.69 \%)$, and positive reappraisal $(50.80 \%)$. Majority of the family caregivers of schizophrenic patients tend to run away (distancing). The caregivers to do distancing because it can reduce their stress. They take a break from concerning themselves with schizophrenic patients for a while.

Schizophrenia is a severe mental illness that affects not only the patient but also his family members. Family members are the primary support system and have the responsibility to care for each other. Caregivers usually provide physical, emotional, and financial supports to their family members who have a mental disorder, such as schizophrenia. ${ }^{19}$ The sense of responsibility that is owned as a family can affect the physical and even mental health of the caregiver. ${ }^{20}$ It is because providing care to schizophrenic patients is a tiring activity that demands patience.

The results of the bivariate analysis by using the Chi-Square statistical test shows that there is no significant relationship between stress levels and coping strategies in family caregivers who treat schizophrenic patients with a history of violent behavior.
It is shown from the value of $\mathrm{p}=0.807$, which is greater than the value of $\alpha=0.05$. The results of this study are similar to those of some existing studies. Furthermore, research in India that assesses the relationship between coping strategies and the level of stress suffered by caregivers shows that there is no significant correlation $(\mathrm{p}=0.258)$ between coping strategies and the level of stress experienced by caregivers. ${ }^{21}$

Besides, a study conducted in a hospital in India shows no correlation between the coping used and the burden experienced by caregivers because the researcher assessed the coping strategies and the burden of nurse caregivers whose patients were undergoing outpatient treatment. On the other hand, in the following study, this condition happens because nurse caregivers are busy with the recovery process for inpatients with schizophrenia, and thus, they understand the problem. ${ }^{22}$ The use of specific coping strategies may be relevant much later in the treatment. ${ }^{22}$ However, a study investigating avoidance shows different results. The use of avoidance coping strategy shows a positive correlation with the burden on schizophrenic caregivers. Moreover, the research shows that there is no consistent correlation between the burden and the PFC strategy.

Based on the results of several studies previously discussed, it is concluded that each coping has different effects. The various research results are possibly influenced by internal and external factors of the caregivers. ${ }^{23}$ Internal factors are individuals' factors, such as health and energy, trust, knowledge, problem-solving skills, social skills, and an individual's communication ability to others. Meanwhile, external factors are factors that come from the outside of an individual. Individual external factors include social support and material resources. Besides, coping strategies can be influenced by several factors, such as life experience, gender, education level, and age. ${ }^{8}$

This study indicates that the stress level that occurs in the family caregivers is categorized as a moderate level. Even though the family caregivers' stress level is at an intermediate level, this situation still requires attention, prevention, management, and treatment appropriately and effectively. Thus, it does not continue to a more severe level. There are even family caregivers who experience stress at an intense level. If the family caregivers experience stress and do not get proper attention, prevention, management, and treatment, the condition will bring a negative impact on physiological, psychological, emotional, cognitive, and behavioral elements. Thus, the results of this study are significant to be implemented by nursing services as an information reference to improve health services through collaboration with academic institutions or universities in providing strategic promotional programs, such as health promotion, counseling, education, and mental nursing cares regarding the management of stress management appropriately and effectively for the family caregivers. 
Correspondence: Giur Hargiana, Department of Mental Health Nursing, Faculty of Nursing, Universitas Indonesia, Jalan Prof. Dr. Bahder Djohan, UI Depok Campus, West Java 16424, Indonesia. Tel. +62.21.78849120 - Fax: +62.21.7864124.

E-mail: giurhargiana@ui.ac.id

Key words: Stress; coping strategies; caregivers; schizophrenia; violent behavior.

Contributions: MJ, concepts and design, data collector, analysis and interpretation of data, drafting and revision of manuscript; GH, concept and design, analysis and interpretation of data, communication with funder.

Conflict of interest: The authors declare no conflict of interest.

Acknowledgments: The authors acknowledge Direktorat Riset dan Pengembangan, Universitas Indonesia for granting the PUTI Saintekes 2020 Number NKB-4609/UN2.RST/HKP.05.00/2020. The author also like to thank the family caregiver of Komunitas Peduli Skizofrenia Indonesia (KPSI) who participated in this study.

Ethics approval and consent to participate: This study has been approved by Ethic Committee of Faculty of Nursing Universitas Indonesia, Depok with Number S-741/UN2.F12.D1/PDP.O4.01/2020. For respondent who participated in the research, fill out the inform consent form.

Availability of data and materials: The datasets analyzed in this study are available from the corresponding author on reasonable request

Conference presentation: This final manuscript has been presented at $7^{\text {th }}$ Virtual Biennial International Nursing Conference, Faculty of Nursing, Universitas Indonesia on September $24^{\text {th }}$, October $30^{\text {th }}$, November $16^{\text {th }} 2020$

Received for publication: 15 August 2020

Accepted for publication: 23 April 2021.

o Copyright: the Author(s), 2021

Licensee PAGEPress, Italy

Journal of Public Health Research 2021; 10(s1):2404

doi:10.4081/jphr.2021.2404

This work is licensed under a Creative Commons Attribution NonCommercial 4.0 License (CC BY-NC 4.0).

\section{References}

1. Stuart G. Principles and pactice of psychiatric nursing. St Louis: Elsevier Mosby; 2013.

2. World Health Organization. Schizophrenia. Geneva: World Health Organization; 2019 Accessed: 2019 August 31. Available from: https://www.who.int/mental health/management/schizophrenia/e $\mathrm{n} /$

3. Ministry of Health, Republic of Indonesia. [Hasil riset kesehatan dasar: riskesdas 2013 (Results of basic health research 2013)].[in Indonesian]. Jakarta: Ministry of Health, Republic of Indonesia. 2013. Available from: https://www.litbang. kemkes.go.id/laporanriset-kesehatan-dasar-riskesdas/

4. Suseno, Krisyowo PG. [Pengaruh tindakan restrain fisik dengan manset terhadap penurunan perilaku kekerasan pada pasien skizofrenia di ruang rawat intensif bima Rumah Sakit Jiwa Grhasia Daerah Istimewa Yogyakarta (Effect of physical restrain measures with cuffs on reducing violent behavior in schizophrenic patients in the intensive care room of the Grhasia Mental Hospital in the Special Region of Yogyakarta)].[Article in Indonesian]. Jurnal Keperawatan Merci 2013;4:1-6.
5. Nolan KA, Czobor P, Roy BB, et al. Characteristics of assaultive behaviour among psychiatric inpatients. Psychiatr Serv 2003;54:1012-6.

6. Mubin M, Andriani T. Gambaran tingkat stres pada keluarga yang memiliki penderita gangguan jiwa di RSUD dr. H. Soewondo Kendal (Stress level on family living with mental disorder patient in RSUD dr. H. Soewondo)].[Article in Indonesian]. Prosiding Seminar Nasional dan Internasional (Proceeding Internation Conference) 2013;1:299-302.

7. Wanti Y, Widianti E, Fitria N. [Gambaran strategi koping keluarga dalam merawat anggota keluarga yang menderita gangguan jiwa berat (An overview of family coping strategies in caring for family members who suffer from serious mental disorders)].[Article in Indonesian]. Padjajaran Nursing Journal 2016;4:89-97.

8. Berman AJ, Snyder S, Frandsen G. Kozier \& Erb's fundamentals of nursing: concepts, practice, and process. 10th ed. New York: Pearson Education, Inc; 2016.

9. Potter PA, Perry AG, Stockert PA, et al. Fundamentals of nursing. 9th ed. St. Louis: Elsevier; 2017.

10. Friedman MM, Bowden VR, Jones EG. Family nursing research, theory, and practice. New York: Pearson Education Inc; 2003.

11. Vasudeva S, Sekhar CK, Rao PG. Caregivers burden of patients with schizophrenia and bipolar disorder: a sectional study. Indian J Psychol Med 2013;35:352-57.

12. Shamsaei F, Cheragi F, Bashirian S. Burden on family caregivers caring for patients with schizophrenia. Iran J Psychiatry 2015;10:239-45.

13. Hsiao CY, Tsai YF. Factors of caregiver burden and family functioning among Taiwanese family caregivers living with schizophrenia. J Clin Nurs 2015;24:1546-56.

14. Kageyama M, Solomon P, Yokoyama K. Psychological distress and violence towards parents of patients with schizophrenia. Arch Psychiatr Nurs 2016;30:614-9.

15. Raj EA, Shiri S, Jangam KV. Subjective burden, psychological distress, and perceived social support among caregivers of persons with schizophrenia. Indian J Soc Psychiatry 2016;32:42-9.

16. Pompeo DA, de Carvalho A, Olive AM, et al. Strategies for coping with family members of patients with mental disorders. Rev Latino Am Enfermagem 2016;24:e2799.

17. Retnowati R, Sriati A, Widiastuti M. [Strategi koping keluarga dalam merawat anggota keluarga penderita skizofrenia di instalasi rawat jalan rumah sakit jiwa Provinsi Jawa Barat (Family coping strategies in caring for family members with schizophrenia in the outpatient installation of a mental hospital in West Java Province)].[Article in Indonesian]. Students e-Journal 2012;1:115.

18. Parasar A, Naik D, Gupta P, et al. A study of coping strategies caregivers of schizophrenia patients. IAHRW Int J Soc Sci 2015;3:354 9.

19. Ebrahim H, Seyedfatemi N, Areshtanab HN, et al. Barriers to family caregivers' coping with patients with severe mental illness in Iran. Qual Health Res 2018;28:987-1001.

20. Riley-McHugh D, Brown CH, Lindo J. Schizophrenia: its psychological effects on family caregiver. Int J Adv Nursg Stud 2016;5:96-101.

21. Geriani D, Savithry KSB, Shivakumar S, Kanchan T. Burden of care on caregivers of schizophrenia patients: a correlation to personality and coping. J Clin Diagnos Res 2015;9:VC01-VC04.

22. Jagannathan A, Thirthalli J, Hamza A, et al. Predictors of family caregiver burden in schizophrenia: study from an in-patient tertiary care hospital in India. Asian J Psychiatr 2014;8:94-8.

23. Townsend M. Essentials of psychiatric mental health nursing. 4th Ed. Philadelphia: F.A. Davis Company; 2008. 